\title{
STUDY ON THE FLOW OF ENERGY AND CARBON DIOXIDE EMBODIED IN INTERNATIONALLY TRADED GOODS AND SERVICES
}

\author{
Ram Sharma TIWAREE*, Ryo FUJIKURA* and Hidefumi IMURA*
}

\begin{abstract}
A model based on standard input-output analysis is applied to account for the net energy consumption and the respective carbon dioxide $\left(\mathrm{CO}_{2}\right)$ emission of a country or a region using the international statistics on trade, energy consumption, $\mathrm{CO}_{2}$ emission etc.

The results of the analysis is that the net import of embodied energy and $\mathrm{CO}_{2}$ by industrialized countries had been increasing steadily. On the other hand, developing countries have increased their net export of embodied energy and $\mathrm{CO}_{2}$ remarkably. Japan's net import of embodied energy and $\mathrm{CO}_{2}$ from developing countries, especially from China, and East Asian countries is quite remarkable in response to their increased trade. Along with the reduction in the amount of direct energy consumption in industrialized countries, their net import of energy and $\mathrm{CO}_{2}$ embodied in goods and services would further increase in future.
\end{abstract}

KEY WORDS: Trade and Environment; Embodied Energy; Embodied $\mathrm{CO}_{2}$.

\section{INTRODUCTION}

International trade may have both positive and negative environmental impacts, although the analysis of these impacts is at a preliminary stage [1]. The positive aspect is the effectiveness of resource use through trade. Further, trade provides the opportunity for the global spread of environmental technologies and services to address specific ecological problems. The negative effect of the trade is that the traded goods and services give rise to various environmental problems throughout the process of their production, transportation, consumption and disposal. A large amount of environmental resources and pollutants embodied in goods and services are also being transacted between the countries. In this respect, it is obvious that international trade is greatly related with global environmental aspects [2].

Globally, trade of $\mathrm{CO}_{2}$ embodied in goods and services between the countries or regions could serve as a basis for assessing the environmental impacts of traded goods and services since $\mathrm{CO}_{2}$ is a major greenhouse gas where site of the source is unimportant [3].

While industrialized countries have been implementing several techno-economic policies to reduce their domestic $\mathrm{CO}_{2}$ emission, the importance of carbon embodied in traded goods and services between the countries are not necessarily taken into account. It is, therefore, meaningful to analyze movement of carbon embodied on international scales, and input-output model is an important tool. The aggregated approach based on input-output analysis can complement the deficiencies of microscopic approach of life cycle assessment (LCA) even though it cannot deal with the microscopic differences of materials [4].

In this respect, the present study analyzes the trade structure of energy and respective $\mathrm{CO}_{2}$ embodied in goods and services, and accounts for the net (direct plus indirect) consumption of energy and respective $\mathrm{CO}_{2}$ emission using the standard input-output model to the available trade, energy, $\mathrm{CO}_{2}$ data for different years in a very simple manner such that a country or region is represented by one economic sector.

\section{CALCULATION OF EMBODIED ENERGY AND ENVIRONMENTAL LOADS}

The standard methodology of input -output analysis [5] which has been extensively applied in the calculation of embodied energy and environmental loads $[6,7,8]$ can be represented by the following equation:

$$
\varepsilon=E(X-Z)^{-1}
$$

Here, $\varepsilon=\left(\varepsilon_{1}, \varepsilon_{2}, \ldots ., \varepsilon_{n}\right)$ is the embodied energy intensity vector, where $\varepsilon_{i}$ denotes the total energy

*Institute of Environmental Systems, Faculty of Engineering, Kyushu University, 36, Fukuoka, 812, Japan 
required for one unit monetary value demand of the $i$-th economic sector; $E=\left(E_{1}, E_{2}, \ldots ., E_{n}\right)$ is the energy input vector, $E_{i}$ being the external input of energy to the $i$-th economic sector; $Z=\left\{Z_{i j}\right\}$ is the input-output table or the transaction matrix between industry sectors; $\mathrm{X}$ is a diagonal matrix, the diagonal element $\mathrm{X}_{\mathrm{ij}}$ being the total demand of the $\mathrm{i}$-th economic sector.

The international trade matrix, which we prepared, has similar structure as that of input-output table if we consider that each country or region is represented by one economic sector. Thus, the model as represented by equation (1) can be directly adapted with minor modifications. Firstly, the suffices " $i$ and $j$ " are replaced by " $\alpha$ and $\beta$ " which denotes country $\alpha$ and $\beta$ (here, $i=\alpha, \beta$ and $j=\beta, \gamma$ ); $Z=\left\{Z_{\alpha \beta}\right\}$ is the international trade matrix which is expressed in monetary values (e.g., US dollar); and $\mathrm{X}$ is the diagonal matrix expressing the total final demand of the countries and/or regions:

$$
\mathrm{X} \beta=\mathrm{Y} \beta+\sum_{\alpha=1}^{\mathrm{n}} \mathrm{Z}_{\alpha \beta}
$$

where, $\mathrm{Y}_{\beta}$ is the gross domestic product (GDP) of the country $\beta$ and the net (direct plus indirect) energy $E_{\beta}(Z)$ used in the country $\beta$ can be expressed in the following way:

$$
E_{\beta}(\mathrm{Z})=E_{\beta}+E_{\beta}(\mathrm{i})-E_{\beta}(e)
$$

where,

$$
E_{\beta}(i)=\varepsilon_{\alpha} \sum_{\alpha} Z_{\alpha \beta}
$$

and

$$
E_{\beta}(e)=\varepsilon_{\beta} \sum_{\gamma} Z_{\beta \gamma}
$$

Equations (4) and (5) are the total energy embodied in the goods and services imported to and exported from the region or country $\beta$, respectively, and $E_{\beta}$ is the direct (domestic) energy input in country or region $\beta$. Here the net import of embodied energy in goods and services in the economy $\beta, E_{\beta}$ (ie), i.e., the indirect energy input in the country $\beta$, can be expressed as

$$
E_{\beta}(i e)=E_{\beta}(Z)-E_{\beta}=E_{\beta}(i)-E_{\beta}(e)
$$

In the present analysis, the above model is applied to the whole world divided into 26 regions and/ or countries: (a) Industrialized countries: USA, Canada, Australia, Japan, France, Germany, Italy, Netherlands, UK, other industrialized countries; (b) developing countries: Africa; Asia : China, India, Dynamic Asian Economies or Dynamic Asia (DAE: Indonesia, Malaysia, Philippines, Singapore, Thailand, Taiwan, Hong Kong, S. Korea), other Asia; Middle -East; Developing Europe; and Western Hemisphere. First of all, trade tables (matrices) are constructed by using the relevant country to country trade data for the years 1978, 1982,1987 and $1992[9,10]$, and necessary calculations using the above model is done accordingly. Data of GDP, primary energy consumption and $\mathrm{CO}_{2}$ emission etc. are extracted and processed from various published international sources wherever necessary $[10,11,12,13,14]$.

\section{RESULTS AND DISCUSSION}

\subsection{Flow of Embodied Energy Among Different Regions}

Figures 1, 2 \& 3 represent the estimated embodied energy flow in the trade of goods and services from and to the US, Japan, and DAE, respectively for the years 1978, 1982, 1987 and 1992.

It can be observed from Figure 1 that although the trade of embodied energy between the United States 
and Canada is always large both in terms of import and export, embodied energy flow to the USA from DAE (especially from Hong Kong, S. Korea and Taiwan) and China is quite remarkable recently. In 1992, amount of embodied energy flow to the US was higher from the developing countries than that from the industrialized countries.

Embodied energy flow from the USA to these countries (mainly to the DAE) is also observed increased
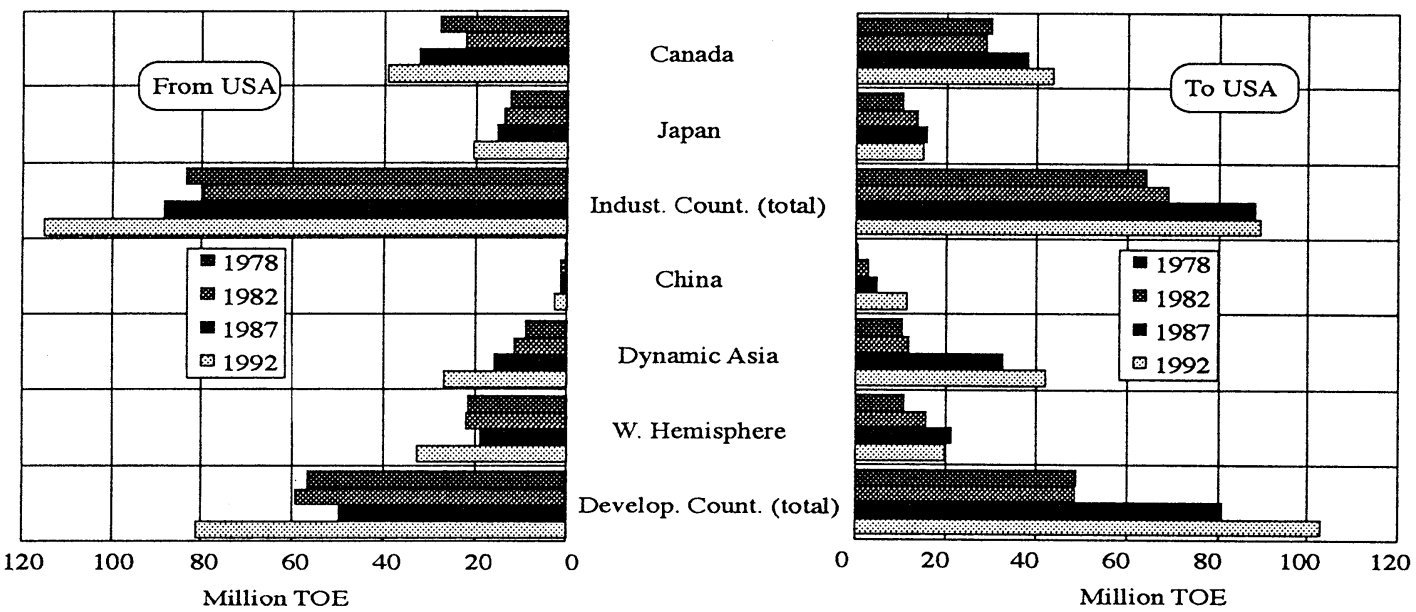

Fig. 1. Flow of Embodied Energy from and to the US

since 1987. USA has also large trade (mainly export) of embodied energy with Western Hemisphere. Additionally, United States' trade of embodied energy with the industrialized countries is always large, and is on increase (mainly export in 1992).

The trade of embodied energy of Japan is also quite remarkable with both industrialized and developing countries along with its increased trade with DAE and China. The largest flow of embodied energy to Japan is accounted for from the DAE (largely from Indonesia and S. Korea) followed by the USA, China and Middle-East in 1992 (Figure 2). In fact, embodied energy flow is being rapidly increased from the USA, China and the DAE to Japan as a result of the furthered close economic relation between these countries or regions and Japan. Japan's import of embodied energy from developing countries has become larger than that from industrialized countries.
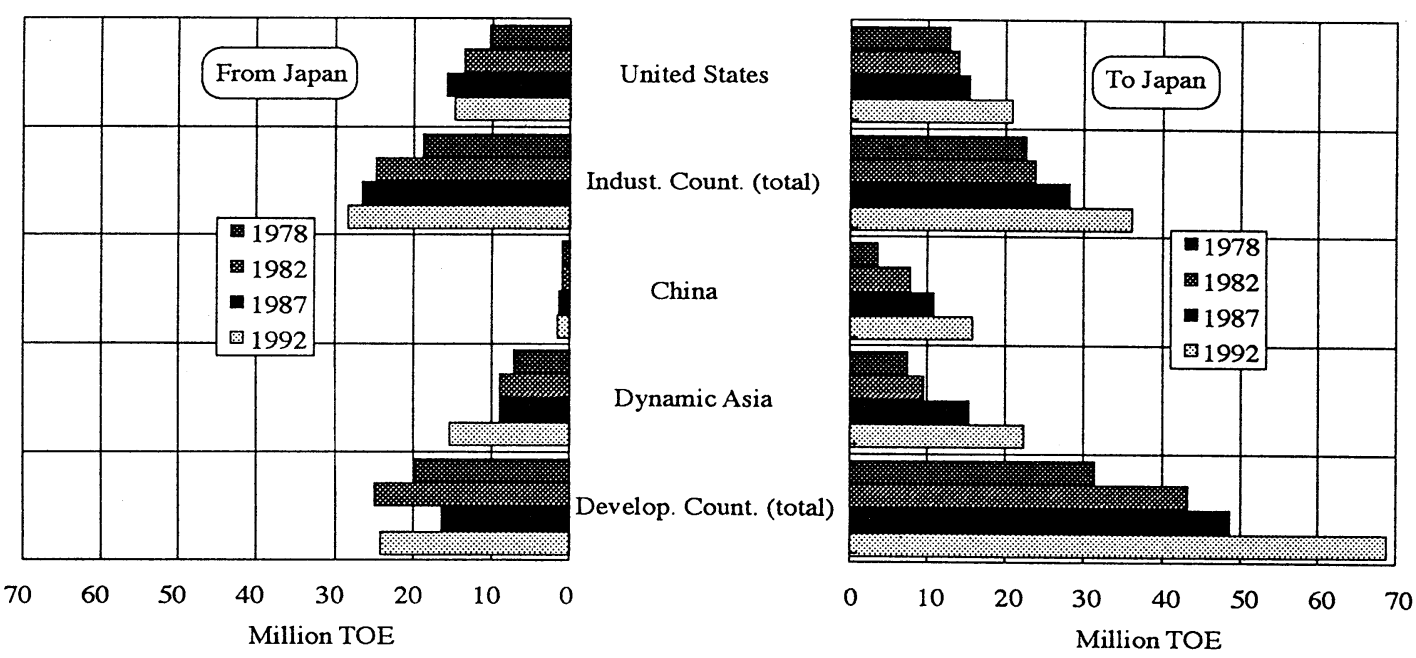

Fig. 2. Flow of Embodied Energy from and to Japan 
Regarding the flow of embodied energy from Japan, that to the DAE during the period 1987 to 1992 is quite high. Overall, Japan's export of embodied energy to industrialized countries is larger than to the developing countries in 1992 with gradual increase to industrialized countries throughout the period (1978 -1992).

Figure 3 represents embodied energy flow from DAE to different regions and vice versa for the years 1978, 1982, 1987 and 1992. The DAE's intra-region trade of embodied energy is quite large. DAE's free trade and export oriented economic policies after 1980s and recently that of China might have, partially,
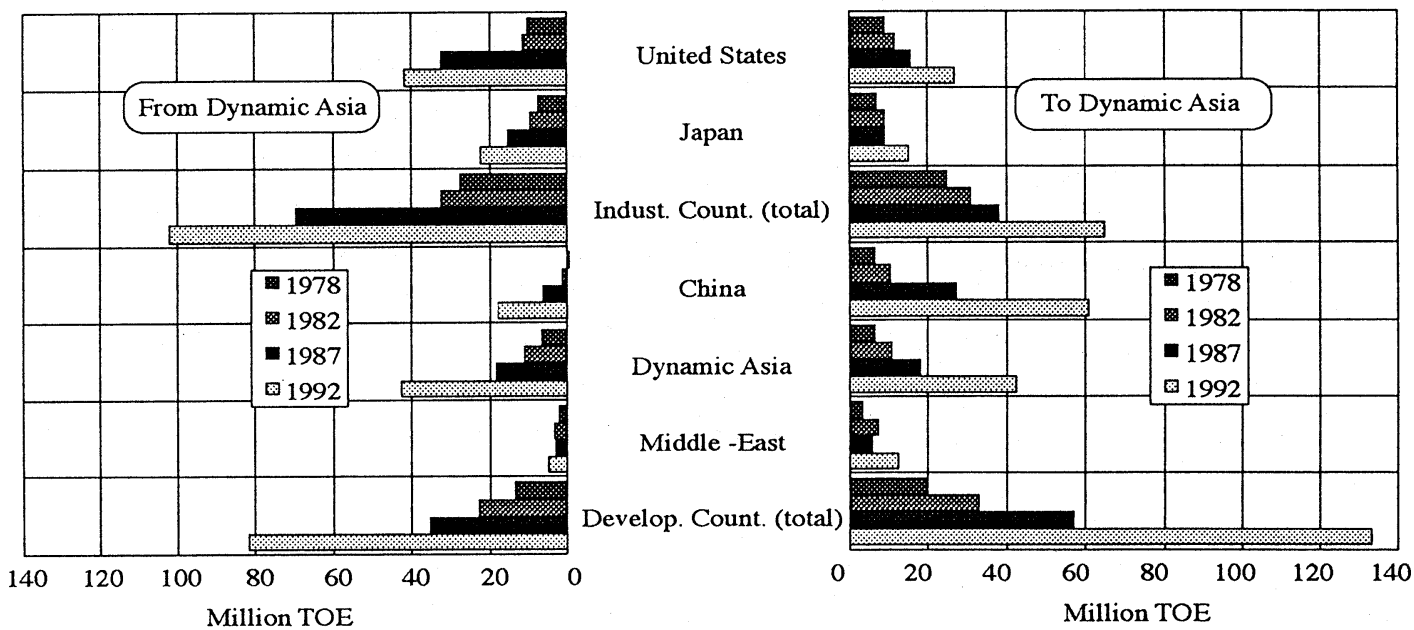

Fig. 3. Flow of Embodied Energy from and to Dynamic Asia

created an environment to relocate many of energy intensive and/or resource based industries, like, iron \& steel; chemicals; non-metallic minerals; building materials from industrialized countries to the DAE countries and have mainly resulted in such growth in trade.

\subsection{Net Import -Export of Embodied Energy Among Different Regions}

Figures 4 represents the net import or net export of embodied energy among different regions (expressed in '000 toe and ' $000 \mathrm{TOE} / \mathrm{capita}$ ). Despite very large inflow and outflow of embodied energy in the US, its net import or net export of embodied energy is comparatively insignificant. On the other hand, the US which was net exporter till 1982 turned its position to net importer in 1987, as a result of sharply increased trade imbalances mainly, with the developing countries including Western Hemisphere, and also due to excessive import of goods under the classification (SITC based) of machinery \& transport equipments; and other manufacturing goods. Western Hemisphere was always the net importer of embodied energy from the US, previously. In 1992 however, the US again changed its position and became its net exporter. So far as Japan is concerned, it is always the largest net importer of embodied energy except in 1978, and has always nearly uniform rise.

On the other hand, Developing Europe, which is the net importer of goods and services in the years $1982,1987,1992$, is, however, the largest net exporter of embodied energy. The main reason is that the average energy consumption to produce an unit of goods and services (expressed in US\$) in Developing Europe is almost five times higher than that of its major trading partners, i.e., the industrialized European countries including Germany. China's major trade of goods and services is with DAE (largely with Hong Kong in 1992), Japan, and the US, and has continuous and uniform rise of net export of embodied energy. Finally, China is also the largest net exporter of embodied energy. This is mainly due to China's rapid growth in the net export of goods and services. Additionally, China has also higher energy consumption to produce an unit of goods and services.

While DAE became once net exporter in 1987 as their rise in export of goods and services, it has again become the net importer of the embodied energy in 1992 due to its large net import of goods and services, 
mainly, from China. In 1987, DAE's import of goods from China was just $4 \%$ higher than its export to China, which, however, became $17 \%$ in 1992. Africa and Middle -East also changed their position to become net exporters in 1987 and 1992. The major cause is that the amount of energy required to produce an unit of goods and services in the United States, EU, Japan, and Eastern Asian countries which are the major trading partners of Africa and Middle-East, was reduced by one-half to two-third in the period while

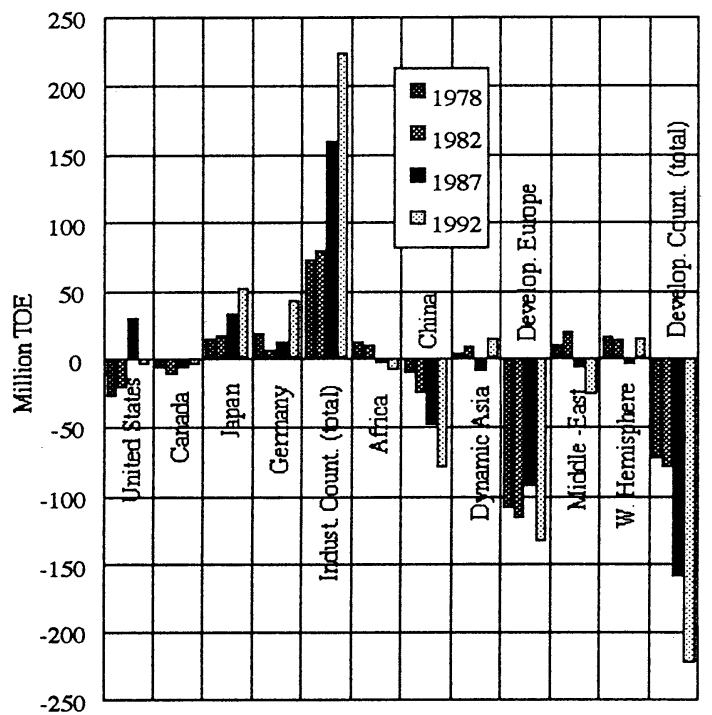

Fig. 4. Net Import of Embodied Energy

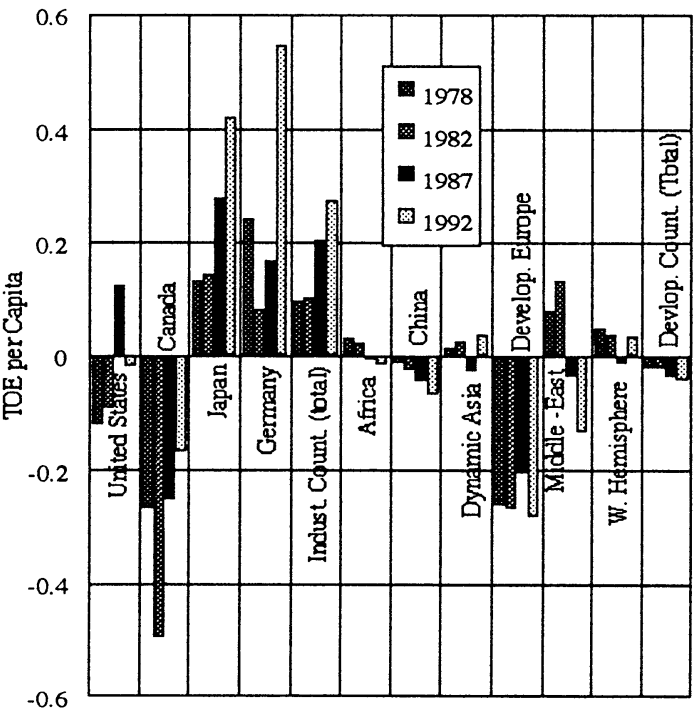

Fig. 5. Per capita Net Import of Embodied Energy

that of them has not changed significantly.

Figure 5 shows the per capita net import or net export of energy embodied in goods and services. In 1992, Germany has the largest net import per capita of embodied energy followed by Japan. The Germany's net export of goods and services was decreased by more than $50 \%$ in 1992 compared to that of 1987 due to the excessive import of energy intensive goods under the category, fuels and lubricants; machines and transport equipments; food and beverages .

Developing Europe and Canada have the largest per capita net export of energy embodied in goods and services. However, Canada's net export of embodied energy in terms of amount is small (Fig. 4). Canada's average energy consumption to produce an unit of goods and services is higher than that of its main trading partners, EU and also the US. Additionally, Canada has the net export of energy intensive goods, mainly, fuel and lubricants; crude materials; construction materials; wooden products.

Most of the industrialized countries are the net importers, and the developing countries are often the net exporters. The difference between industrialized and developing countries (both in terms of ' 000 toe and ' 000 toe per capita) has become more pronounced with the rise in their trade volume in recent years. In 1992 , industrialized countries' net import of embodied energy per capita was 0.276 TOE/capita, while the developing countries' net export of embodied energy per capita was $0.041 \mathrm{TOE} /$ capita.

\subsection{Trade Ecobalance of Embodied Carbon DioxideAmong Different Regions}

The above results obtained for the embodied energy flow is convertible into the flow of embodied $\mathrm{CO}_{2}$ by using the emission coefficients of fossil fuels $[12,13]$. Table 1 represents the ratio of $\mathrm{CO}_{2}$ emission to energy consumption for the years 1978, 1982, $1987 \& 1992$ in different countries and/or regions. It can be observed that the ratio of the domestic (direct) $\mathrm{CO}_{2}$ emission to the corresponding energy consumption in industrialized countries has smooth fall while that, principally, in Asia (China, DAE, Other Asia), and Africa, is quite insignificant. Accordingly, the ratio of $\mathrm{CO}_{2}$ to energy embodied in imported goods and services (the "import" column in Table 1) for industrialized countries is larger than that for developing countries. 
Table 1. Ratio of $\mathrm{CO}_{2}$ Emission to Energy Consumption (T-C/TOE)

\begin{tabular}{|l|r|r|r|r|r|r|r|r|r|r|r|r|}
\hline \multicolumn{1}{r|}{ Year } & \multicolumn{3}{|c|}{1978} & \multicolumn{3}{c|}{1982} & \multicolumn{3}{c|}{1987} & \multicolumn{3}{c|}{1992} \\
\hline Country Ratio & Direct & Net & Import & Direct & Net & Import & Direct & Net & Import & Direct & Net & Import \\
\hline United States & 0.74 & 0.74 & 0.79 & 0.73 & 0.74 & 0.75 & 0.72 & 0.72 & 0.71 & 0.71 & 0.71 & 0.73 \\
\hline Canada & 0.64 & 0.63 & 0.76 & 0.61 & 0.63 & 0.74 & 0.56 & 0.59 & 0.73 & 0.58 & 0.60 & 0.72 \\
\hline Japan & 0.78 & 0.74 & 0.81 & 0.72 & 0.74 & 0.81 & 0.66 & 0.68 & 0.78 & 0.68 & 0.70 & 0.77 \\
\hline Germany & 0.82 & 0.76 & 0.84 & 0.76 & 0.76 & 0.77 & 0.72 & 0.72 & 0.73 & 0.74 & 0.73 & 0.70 \\
\hline Indust. count. (rest) & 0.86 & 0.74 & 0.84 & 0.72 & 0.74 & 0.77 & 0.66 & 0.68 & 0.73 & 0.67 & 0.68 & 0.71 \\
\hline Indust. Count. (total) & 0.78 & 0.73 & 0.82 & 0.73 & 0.73 & 0.77 & 0.69 & 0.70 & 0.73 & 0.69 & 0.70 & 0.72 \\
\hline Africa & 0.92 & 0.88 & 0.83 & 0.91 & 0.88 & 0.77 & 0.75 & 0.73 & 0.75 & 0.89 & 0.87 & 0.73 \\
\hline China & 0.98 & 0.98 & 0.82 & 0.98 & 0.98 & 0.78 & 0.99 & 0.98 & 0.79 & 0.98 & 0.97 & 0.79 \\
\hline India & 0.92 & 0.90 & 0.83 & 0.91 & 0.90 & 0.79 & 0.89 & 0.88 & 0.76 & 0.90 & 0.89 & 0.74 \\
\hline Dynamic Asia & 0.83 & 0.81 & 0.83 & 0.82 & 0.81 & 0.80 & 0.74 & 0.75 & 0.81 & 0.76 & 0.77 & 0.81 \\
\hline Other Asia & 0.86 & 0.88 & 0.83 & 0.89 & 0.88 & 0.81 & 1.00 & 0.97 & 0.81 & 0.94 & 0.92 & 0.80 \\
\hline Develop. Europe & 0.86 & 0.83 & 0.85 & 0.83 & 0.83 & 0.80 & 0.80 & 0.80 & 0.79 & 0.66 & 0.67 & 0.70 \\
\hline Middle - East & 0.79 & 0.81 & 0.82 & 0.82 & 0.81 & 0.79 & 0.91 & 0.92 & 0.77 & 0.71 & 0.72 & 0.73 \\
\hline W. Hemisphere & 0.78 & 0.74 & 0.79 & 0.74 & 0.74 & 0.76 & 0.71 & 0.71 & 0.72 & 0.70 & 0.70 & 0.72 \\
\hline Develop. Count. (total) & 0.87 & 0.84 & 0.82 & 0.85 & 0.84 & 0.79 & 0.83 & 0.83 & 0.78 & 0.77 & 0.77 & 0.76 \\
\hline World (total) & 0.82 & 0.78 & 0.82 & 0.78 & 0.78 & 0.78 & 0.76 & 0.76 & 0.75 & 0.73 & 0.73 & 0.73 \\
\hline
\end{tabular}

Figure 6 shows the per capita net import or net export of $\mathrm{CO}_{2}$ embodied in goods and services for different years. In 1992, Japan followed by Germany has the highest net import per capita. It is mainly due to the higher value of the ratio of $\mathrm{CO}_{2}$ to energy (T-C/TOE) in the imported goods and services in Japan than that of Germany. On the other hand, the developing Europe has the largest net export in 1992. Canada which was net exporter till 1982, has changed its position to become the net importer in 1987 and 1992. The reason is the increased difference in the ratio of $\mathrm{CO}_{2}$ emission to energy consumption of locally produced and of imported goods and services (Table 1).

Overall, industrialized countries have the high net import of embodied $\mathrm{CO}_{2}$ per capita, i.e., $0.226 \mathrm{~T}-\mathrm{C} /$ Capita and that of developing countries is $0.039 \mathrm{~T}-\mathrm{C} /$ Capita in 1992.

\subsection{Contribution of Embodied Carbon Dioxides to Global Emission}

The per capita domestic energy consumption or the respective per capita $\mathrm{CO}_{2}$ emission in both industrialized and developing economies is still on rise and have a linear relationship with economic development. The trade of energy or $\mathrm{CO}_{2}$ embodied in goods and services between these two economies is also on rise. While industrialized countries have very

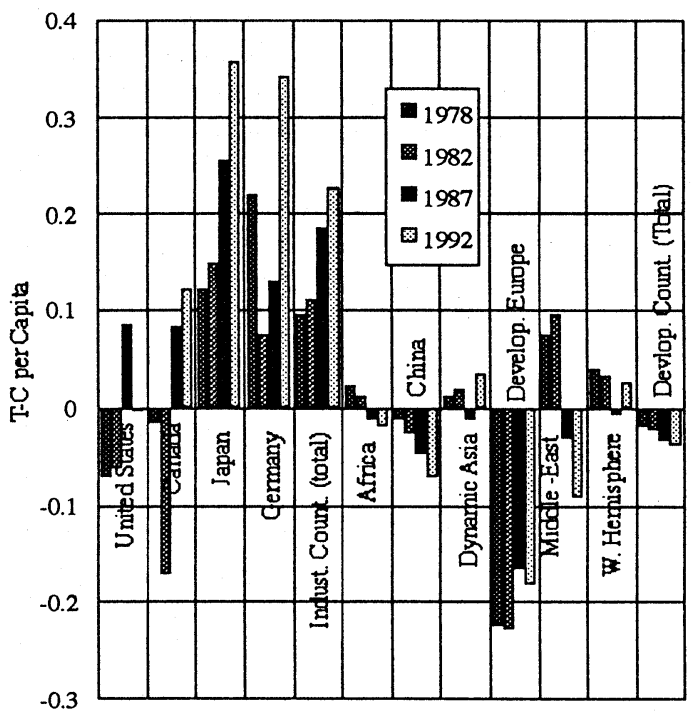

Fig. 6. Per Capita Net Import of Embodied $\mathrm{CO}_{2}$ high per capita domestic energy consumption as well as respective $\mathrm{CO}_{2}$ emission $(5.12 \mathrm{TOE} /$ capita and $3.55 \mathrm{~T}-\mathrm{C} /$ capita in 1992) compared to that of developing countries $(0.8 \mathrm{TOE} /$ capita and $0.62 \mathrm{~T}-\mathrm{C} /$ capita in 1992), they have constantly increased their net import of embodied energy or embodied $\mathrm{CO}_{2}$. When we add the net import of $\mathrm{CO}_{2}$ embodied in goods and services, industrialized countries' total emission of $\mathrm{CO}_{2}$ becomes larger. The ratio of net import of embodied $\mathrm{CO}_{2}$ to its domestic emission for industrialized countries which was $3 \%$ and $3.42 \%$ in 1978 and 1982, respectively, was doubled to $6.37 \%$ in 1992 (Fig. 7).

This suggests that the import of more carbon intensive goods largely from developing countries might contribute partially in the reduction or, at least, stabilization of domestic $\mathrm{CO}_{2}$ emission by industrialized countries with a possibility of win-win-lose situations [15]. The industrialized countries would win because their domestic $\mathrm{CO}_{2}$ emission would be reduced; the developing countries would also win because they receive the benefit of an economic growth due to their increased industrialization. However, the likely result would be at best, do little to reduce global emissions, and at worst, might even increase it. In Asia- 
Pacific rim, Japan, and China and DAE seem to represent such situations as their ecological and economic interdependency is on increase.

\section{CONCLUSIONS}

In this study, we have analyzed the trade of energy and $\mathrm{CO}_{2}$ embodied in goods and services among different countries and/or regions using the standard input-output model to the available country to country trade, energy, $\mathrm{CO}_{2}$ data etc. assuming a country or a region as one economic sector, and discussed, impact of trade on global environment problem where site of the pollution is unimportant.

The gap in direct energy consumption or the respective $\mathrm{CO}_{2}$ emission between the industrialized and the developing countries is observed quite large and is further widened if we add their net import input of energy or $\mathrm{CO}_{2}$ embodied in goods and services. Industrialized countries might reduce their domestic emission of $\mathrm{CO}_{2}$ in future. Some part of the reduction would be, however, due to the import of emdobied $\mathrm{CO}_{2}$ from developing countries. This trend would be further on rise as the economy globalized.

\section{REFERENCES}

1. OECD: The Environmental Effects of Trade, OECD Publication, Paris, 1994.

2. Rфpke, I.: Trade, Development and Sustainability - a Critical Assessment of the "Free Trade Dogma", Ecological Economics 9,1994, pp. 13 - 22.

3. Steininger, K.: Reconciling Trade and Environment : Towards a Comparative Advantage for Long Term Policy Goals, Ecological Economics 9, 1994, pp. 23 - 42.

4. Tiwaree, R.S. et al:: An International Aspect of LCA : Trade EcoBalance of Goods and Services, International Conference on EcoBalance, Tsukuba, Japan, October 1994, pp. 263 - 268.

5. Miller, R. E. and Blair, P.D.: Input-Output Analysis, Foundation and Extensions, Prentice - Hall, New Jersey, 1985.

6. Gay, P.W. and Proops, J.L.R.: Carbon Dioxide Production by the UK Economy: An Input-Output Assessment, Applied Energy 44, 1993, pp. 113 - 130.

7. Imura, H. et al.: Study on the Export -Import Balance of Environmental Loads Pertinent to the International Trade of Goods and Services, Environmental Science, 7 (3), 1994, pp. 225 - 236 (in Japanese).

8. Tiwaree, R.S. and Imura, H.: Input-Output Assessment of Energy Consumption and Carbon Dioxide Emission in Asia, Environmental Systems Research, 22, 1994, pp. 376 - 382.

9. IMF: Direction of Trade Statistics, International Monetary Fund, 1994, 1987.

10. WB: World Table 1994 (in CD-ROM), World Bank, Washington, DC, 1994.

11. IEA: Energy Balances of OECD Countries; World Energy Statistics and Balances, OECD Publication, Paris (different issues).

12. OECD: OECD Environmental Data, OECD Publication, Paris, 1993.

13. David von Hippel et al.: Estimating Greenhouse Gas Emissions from Fossil Fuel Consumption: Two Approaches, Energy Policy, June 1993, pp. 691 - 702.

14. UNEP: Environmental Data Report, 1993-94, Blackwell Publishers, U.K., 1993.

15. Wyckoff, A.W. and Roop, J. M.: The Embodiment of Carbon in Imports of Manufactured ProductsImplications for International Agreements on Greenhouse Gas Emissions, Energy Policy, March 1994, pp. 187 - 193. 